\title{
Analisis Kecenderungan Zona Nilai Tanah di Wilayah Surabaya Menggunakan Multiple Correspondence Analysis
}

\author{
Desy Ariyanti dan Agus Suharsono \\ Departemen Statistika, Fakultas MIPA, Institut Teknologi Sepuluh Nopember (ITS) \\ e-mail: agus_s@statistika.its.ac.id
}

\begin{abstract}
Abstrak-Kota Surabaya memiliki jumlah penduduk yang terus menigkat setiap tahunnya. Sedangkan ketersediaan lahan di Surabaya tidak sebanding dengan pertambahan jumlah penduduk. Hal ini mengakibatkan kebutuhan akan lahan tanah sebagai tempat tinggal akan meningkat sehingga harga tanah akan semakin tinggi. BPN sebagai lembaga pemerintah yang bertugas di bidang pertanahan menetapkan Zona Nilai Tanah (ZNT) sebagai acuan dalam penentuan harga tanah di wilayah Kota Surabaya. Penentuan ZNT didasarkan pada harga pasar tanah di wilayah tertentu. Selain itu harga tanah juga dipengaruhi oleh wilayah dan tersedianya fasilitas umum. Untuk mengetahui kecenderungan variabel ZNT, banyaknya fasilitas umum dan pembagian wilayah di Kota Surabaya dilakukan penelitian dengan menggunakan analisis kecenderungan dua / lebih variabel kategori dengan menggunakan Multiple Correspondence Analysis (MCA). Dalam analisis ini didapatkan bahwa ZNT memiliki hubungan saling ketergantungan dengan fasilitas umum dan pembagian wilayah. Dalam analisis ini didapatkan bahwa ZNT memiliki kedekatan dengan fasilitas umum dan pembagian wilayah. Hasil MCA menunjukkan terbentuk kelompok-kelompok yang memiliki tingkat kecenderungan yang tinggi yaitu wilayah Surabaya Barat berada di ZNT3 dengan banyaknya fasilitas umum lebih dari 15 unit. Wilayah Surabaya Timur memiliki kecenderungan pada ZNT 2. Sedangkan Surabaya Selatan cenderung pada ZNT 4 dengan jumlah fasilitan umum antara 3 hingga 15 unit.
\end{abstract}

Kata Kunci-Fasilitas Umum, MCA, Surabaya, ZNT

\section{PENDAHULUAN}

$\mathrm{S}$ URABAYA merupakan ibukota Provinsi Jawa Timur yang memiliki penduduk terbanyak kedua di Indonesia setelah Kota Jakarta. Jumlah penduduk di Surabaya selalu mengalami peningkatan setiap tahun. Jumlah penduduk pada tahun 2013 yaitu 2.821.929 jiwa dan mencapai 2.833.924 jiwa pada tahun 2014. Pada tahun 2015 penduduk Kota Surabaya mengalami peningkatan menjadi 2.848.583 jiwa [1]. Meningkatnya jumlah penduduk di Surabaya tidak sebanding dengan luas wilayah yang tidak mengalami peningkatan sehingga kepadatan penduduk di Surabaya semakin besar dan dapat berpengaruh terhadap kebutuhan tempat tinggal yang akan semakin meningkat. Jumlah lahan yang terbatas mengakibatkan tingginya harga tanah di wilayah padat penduduk. Penentuan tinggi atau rendahnya harga tanah tentunya dipengaruhi oleh harga pasar dan juga faktor aksesibilitas tanah yang akan dijual. Apabila lokasi semakin jauh dari pusat kota/ perekonomian maka dapat menurunkan nilai tanah begitupun sebaliknya. Sehingga perlu dibuat suatu acuan dalam penentuan harga tanah yaitu dengan menggunakan Zona Nilai Tanah (ZNT). ZNT merupakan salah satu tolok ukur yang digunakan dalam menentukan harga tanah di suatu wilayah tertentu yang ditentukan dan dibuat oleh Badan Pertanahan Nasional (BPN). BPN merupakan instansi non kementrian yang memiliki tugas di bidang pertanahan secara nasional, regional dan sektoral sesuai dengan ketentuan peraturan perundang-undangan [2] Peta ZNT dapat memberikan gambaran informasi nilai tanah dalam bentuk klasifikasi nilai tanah dengan tujuan agar masyarakat dapat memiliki acuan dalam transaksi pertanahan dan properti di suatu wilayah tertentu. Harga tanah yang tinggi seharusnya didukung oleh tersedianya fasilitas umum yang memadai. Lokasi wilayah juga dapat menjadi salah satu pertimbangan dalam menentukan harga tanah. Untuk mengetahui hubungan asosiasi antara ZNT, dengan banyaknya fasilitas umum dan pembagian wilayah maka dapat dilakukan analisis kualitatif yaitu salah satunya dengan multiple correspondence analysis (MCA). MCA merupakan teknik multivariat yang berguna untuk menganalisis asosiasi dalam sebuah kumpulan data kategorik dengan banyak variable [3]. Penelitian mengenai faktor-faktor yang berpengaruh terhadap nilai tanah pernah dilakukan di Kota Semarang yang menunjukkan bahwa faktor yang mempengaruhi nilai tanah yaitu kepadatan penduduk, jarak ke pusat kota, kondisi jalan, tersedianya fasilitas transportasi umum dan faktor lingkungan [4]. Sedangkan penelitian mengenai hubungan asosiasi lebih dari dua variabel menggunakan MCA pernah dilakukan untuk pemetaan terhadap persepsi merk laptop di kalangan mahasiswa dan menunjukkan hasil bahwa dengan pemetaan persepsi merk laptop dapat diketahui merk laptop yang memiliki tingkat kemiripan yang dekat [5]. Berdasarkan latar belakang di atas dan penelitian yang pernah dilakukan maka dalam penelitian ini akan dilakukan analisis mengenai ZNT di kota Surabaya dengan metode multiple correspondence analysis (MCA) dengan harapan dapat mengetahui kecenderungan antara harga ZNT dengan pembagian wilayah dan ketersediaan fasilitas umum di Kota Surabaya.

\section{TINJAUAN PUSTAKA}

\section{A. Statistika Deskriptif}

Penyajian statistika deskriptif dapat disajikan dalam bentuk mean, median, modus ataupun secara visual dalam bentuk grafik atau diagram seperti diagram batang. Diagram batang digunakan untuk menyajikan data yang bersifat kategori atau data distribusi.

\section{B. Tabel Kontingensi}

Tabel kontingensi atau tabulasi silang menggambarkan dua atau lebih variabel secara simultan dan hasilnya ditampilkan dalam bentuk tabel yang menggambarkan distribusi bersama dua variabel / lebih dengan kategori yang terbatas [6]. Tabel kontingensi tiga dimensi merupakan tabel 
kontingensi yang terdiri dari tiga variabel dengan variabel satu terdiri dari $i$ kategori, variabel kedua $j$ kategori dan variabel ketiga $k$ kategori. Tabel kontingensi berukuran $i j k$ dengan $i$ menyatakan baris, $j$ menyatakan kolom dan $k$ menyatakan layer ke- $k$.

\section{Multiple Correspondence Analysis (MCA)}

MCA merupakan pengembangan dari metode analisis korespondensi yang memungkinkan untuk menganalisis pola hubungan dari beberapa kategori variabel dependen. Secara teknis MCA didapatkan dengan menggunakan analisis korespondensi pada matriks indikatornya [7].

Matriks indikator $\mathbf{X}$ tersusun oleh elemen 0 dan 1, dimana 1 merepresentasikan bahwa suatu unit masuk dalam suatu kategori dan 0 tidak terindikasi memiliki sebuah karakteristik. Total dari setiap baris dari $\mathrm{X}$ adalah 1 dan didapatkan bentuk dari matriks $\mathrm{X}$ yaitu

$$
\mathbf{X}=\left[\mathbf{X}_{1}\left|\mathbf{X}_{2}\right| \cdots \mid \mathbf{X}_{p}\right]
$$

$p$ merupakan banyak variabel kategori dan matriks $\mathbf{X}$ memiliki $n \times J$ dengan $J$ merupakan total kategori variabel. Berdasarkan matriks indikator tersebut selnajutnya dapat dibentuk matrik Burt. Matriks Burt merupakan hasil tabulasi silang dari matriks indikator gabungan variabel-variabel kategorinya sehingga baris dan kolom dari semua variabel asli dapat dianalisis. Bentuk dan perhitungan matriks Burt didapatkan dari persamaan berikut.

$$
\begin{gathered}
\mathbf{B}=\mathbf{X}^{\mathbf{T}} \mathbf{X} \\
\mathbf{B}=\left\{b_{i j}\right\}=\left[\begin{array}{cccc}
X_{1}{ }^{T} X_{1} & X_{1}{ }^{T} X_{2} & \mathrm{~K} & X_{1}{ }^{T} X_{p} \\
X_{2}{ }^{T} X_{1} & X_{2}{ }^{T} X_{2} & \mathrm{~K} & X_{2}{ }^{T} X_{p} \\
\mathrm{M} & \mathrm{M} & \mathrm{O} & \mathrm{M} \\
X_{p}{ }^{T} X_{1} & X_{p}{ }^{T} X_{2} & \mathrm{~K} & X_{p}{ }^{T} X_{p}
\end{array}\right]
\end{gathered}
$$

Selanjutnya matriks korespondensi dibentuk dengan cara membagi matriks Burt dengan jumlah total nilai elemen matriks Burt yaitu $n=\sum_{i j} b_{i j}$ sehingga matriks korespondensi memiliki formula sebagai berikut.

$$
\mathbf{P}=\frac{b_{i j}}{n}
$$

Pendekatan yang digunakan untuk mendapatkan nilai dekomposisi dalam MCA yaitu dengan SVD (Singular Value Decomposition) [8]. SVD merupakan salah satu metode yang sangat berguna dalam konsep aljabar matriks dan konsep eigen decomposition yang terdiri dari eigenvalue serta eigenvector. Tujuannya untuk mereduksi dimensi data berdasarkan keragaman data (nilai eigen/inersia) terbesar dengan mempertahankan informasi yang optimum. SVD didapatkan dari matriks standar residual yang ditunjukkan oleh formula berikut

$$
\mathbf{S}=\mathbf{D}_{r}^{-1 / 2}\left(\mathbf{P}-\mathbf{r r}^{T}\right) \mathbf{D}_{c}^{-1 / 2}
$$

$\mathbf{D}_{r}$ merupakan elemen diagonal matriks $\mathbf{r}$ yaitu massa baris dan $\mathbf{D}_{c}$ diagonal elemen c. Penguraian nilai singular dari matriks residual standar $\mathbf{S}$ yaitu

$$
\mathbf{S}=\mathbf{U} \Sigma \mathbf{U}^{T}
$$

dimana $\boldsymbol{\Sigma}$ merupakan matriks diagonal $n \times n$ dari nilai singular yang berurutan dari terbesar sampai terkecil sedangkan matriks $\mathbf{U}$ memuat vektor singular. Nilai singular dicari untuk memperoleh koordinat baris dan kolom sehingga hasil analisis korespondensi dapat divisualisasikan dalam bentuk grafik.
Berdasarkan dari matriks indikator $\mathbf{X}$, dapat didapatkan koordinat utama profil kolom dan baris sebagai persamaan (6) dan (7).

$$
\begin{aligned}
\mathbf{G} & =\mathbf{U D}_{c}^{-1 / 2} \boldsymbol{\Sigma} \\
\mathbf{F} & =\mathbf{D}_{r}^{-1 / 2} \mathbf{U} \boldsymbol{\Sigma}
\end{aligned}
$$

Sedangkan nilai total inersia didapatkan dengan dengan cara menghitung trace dari hasil kali matriks residual (S) dengan matriks residual transposenya yang ditunjukkan pada persamaan (8) [9].

$$
\text { total inersia }=\operatorname{trace}\left(\mathbf{S S}^{T}\right)
$$

\section{Zona Nilai Tanah}

Zona nilai tanah atau ZNT merupakan zona yang menggambarkan nilai tanah yang relatif sama dari sekumpulan bidang tanah didalamnya dengan batasnya bisa bersifat imajiner ataupun nyata sesuai dengan penggunaan tanah dan mempunyai perbedaan nilai antara satu dengan yang lainnya berdasarkan analisis petugas dengan metode perbandingan harga pasar dan biaya [7].

Tabel 1.

Klasifikasi Kelas Harga ZNT

\begin{tabular}{cc}
\hline \hline Kelas & Harga \\
\hline 1 & Rp. 606.300 - Rp. 2.178.000 \\
2 & Rp. 2.179.000 - Rp. 3.153.000 \\
3 & Rp. 3.154.000 - Rp. 4.983.000 \\
4 & Rp. 4.984.000 - Rp. 15.000.000 \\
\hline \hline
\end{tabular}

E. Pembagian Wilayah

Wilayah adalah ruang yang merupakan kesatuan geografis beserta segenap unsur yang terkait padanya, yang batas dan sistemnya ditentukan berdasarkan aspek administratif dan atau aspek fungsional. Pembagian wilayah Kota Surabaya yaitu dibagi berdasarkan fungsi administrasi dan fungsional yaitu Surabaya Utara, Timur, Pusat, Selatan dan Barat [10].

\section{F. Fasilitas Umum}

Fasilitas umum merupakan sarana prasarana milik pemerintah/swasta yang dapat digunakan oleh semua masyarakat. Fasilitas umum yang digunakan dalam penelitian ini dikategorikan berdasarkan banyaknya fasilitas umum di setiap unit penelitian dengan klasifikasi kelas sebagai berikut

Tabel 2.

Klasifikasi Banyak Fasilitas Umum

\begin{tabular}{cc}
\hline \hline Kelas & Keterangan \\
\hline A & Banyak fasilitas umum $<3$ unit \\
B & Banyak fasilitas umum $3-15$ unit \\
C & Banyak fasilitas umum $>15$ unit \\
\hline \hline
\end{tabular}

\section{METODOLOGI PENELITIAN}

\section{A. Sumber Data}

Data yang digunakan dalam penelitian ini merupakan data sekunder yang diperoleh dari Badan Pertanahan Nasional (BPN) Kantor Wilayah Jawa Timur Bidang Pengadaan Tanah yaitu data tentang zona nilai tanah di wilayah Kota Surabaya tahun 2015 . 


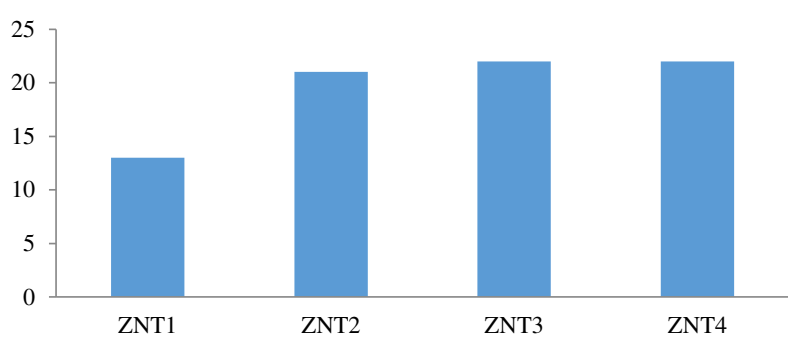

Gambar 1. Frekuensi zona nilai tanah.

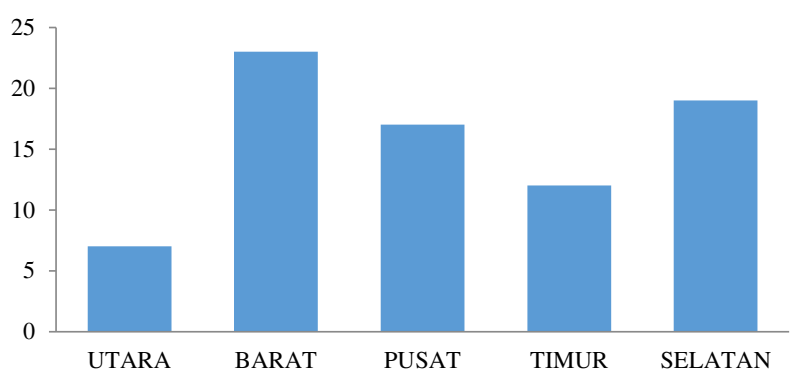

Gambar 2. Frekuensi pembagian wilayah Surabaya.

\section{B. Variabel Penelitian}

Variabel yang digunakan dalam penelitian ini merupakan variabel kategorik yang ditampilkan pada tabel 3 berikut.

Tabel 3.

Variabel Penelitian

\begin{tabular}{cll}
\hline \hline Variabel & \multicolumn{1}{c}{ Nama Variabel } & \multicolumn{1}{c}{ Keterangan } \\
\hline $\mathrm{Y}_{1}$ & Pembagian Wilayah & 1: Surabaya Utara \\
& Surabaya & 2: Surabaya Barat \\
& & 3: Surabaya Pusat \\
& & 4: Surabaya Timur \\
& & 5: Surabaya Selatan \\
$\mathrm{Y}_{2}$ & Banyak Fasilitas & A: fasilitas < 3 unit \\
& Umum & B: fasilitas 3-15 unit \\
& & C: fasilitas $>15$ unit \\
$\mathrm{Y}_{3}$ & Zona Nilai Tanah & 1: ZNT 1 \\
& (ZNT) & 2: ZNT 2 \\
& & 3: ZNT 3 \\
&
\end{tabular}

C. Langkah Analisis

Analisis yang dilakukan pada penelitian ini memiliki beberapa langkah yaitu sebagai berikut.

1. Mendeskripsikan setiap karakteristik variabel ZNT, pembagian wilayah, dan banyaknya fasilitas umum di wilayah Kota Surabaya menggunakan diagram batang.

2. Membuat tabel kontingensi variabel ZNT, pembagian wilayah dan banyak fasilitas umum.

3. Melakukan analisis Multiple Correspondence Analysis pada data ZNT, pembagian wilayah di Kota Surabaya dan banyaknya fasilitas umum dengan langkah sebagai berikut.

a. Membuat matriks indikator data ZNT, pembagian wilayah dan banyak fasilitas umum di Kota Surabaya seperti pada persamaan (1).

b. Menghitung matriks Burt dengan mengalikan matriks indikator dengan matriks indikator transposenya (persamaan 2)

c. Menghitung nilai inersia dari hasil matriks standar residual (5) d. Menghitung profil kolom dan baris untuk data ZNT terhadap pembagian wilayah dan banyak fasilitas umum di Kota Surabaya

e. Memvisualisasi plot antara profil vektor baris dan profil vektor kolom data ZNT dengan fasilitas umum dan ZNT dengan wilayah

4. Menginterpretasi plot hasil analisis ZNT terhadap pembagian wilayah dan fasilitas umum dengan multiple correspondence analysis.

5. Menarik kesimpulan

\section{ANALISIS DAN PEMBAHASAN}

\section{A. Karakteristik Data}

Pada analisis ini karakteristik data digambarkan dengan menggunakan diagram batang yang menunjukkan frekuensi setiap variabel secara individu serta frekuensi setiap variabel terhadap variabel lainnya. Gambar 1 menunjukkan frekuensi zona nilai tanah untuk masing-masing kelas interval. Sedangkan pada Gambar 2 menunjukkan frekuensi pengamatan berdasarkan pembagian wilayah di Kota Surabaya dan pada Gambar 3 menunjukkan banyaknya fasilitas umum pada setiap kelas.

Diagram tersebut menunjukkan bahwa ZNT 1 memiliki jumlah sebesar 13 unit dengan harga tanah berkisar kurang dari Rp 2.178.000. ZNT tertinggi kedua yaitu ZNT 2 sebanyak 21 unit dengan kisaran harga tanah antara $\mathrm{Rp}$ 2.179.000 hingga Rp 3.153.0000. ZNT 3 dan ZNT 4 memiliki nilai yang sama yaitu sebanyak 22 unit. ZNT 3 memiliki harga tanah antara Rp 3.154.000 hingga Rp 4.983.000 sedangkan ZNT 4 memiliki kisaran harga antara Rp 4.984.000 hingga Rp 15.000.000. Berdasarkan hasil grafik tersebut menunjukkan bahwa harga tanah di wilayah Kota Surabaya rata-rata bernilai sebesar 4 juta rupiah.

Apabila dilihat dari sisi wilayah, disajikan diagram batang yang menunjukkan frekuensi masing-masing wilayah yaitu Surabaya Utara, Surabaya Barat, Surabaya Pusat, Surabaya Timur dan Surabaya Selatan.

Wilayah Surabaya Barat memiliki nilai tertinggi yaitu sebesar 23 dan wilayah tertinggi kedua yaitu Surabaya Selatan dengan frekuensi 19. Data tersebut menunjukkan bahwa sebesar 19 zona pengamatan berada di wilayah Surabaya Selatan. Surabaya Pusat memiliki nilai yang terbesar ketiga yaitu 17 sedangkan Surabaya Timur memiliki nilai sebesar 12. Wilayah dengan frekuensi paling kecil yaitu 7 berada di Surabaya Utara. Berdasarkan banyaknya fasilitas umum dapat dilihat pada diagam batang Gambar 3 berikut.

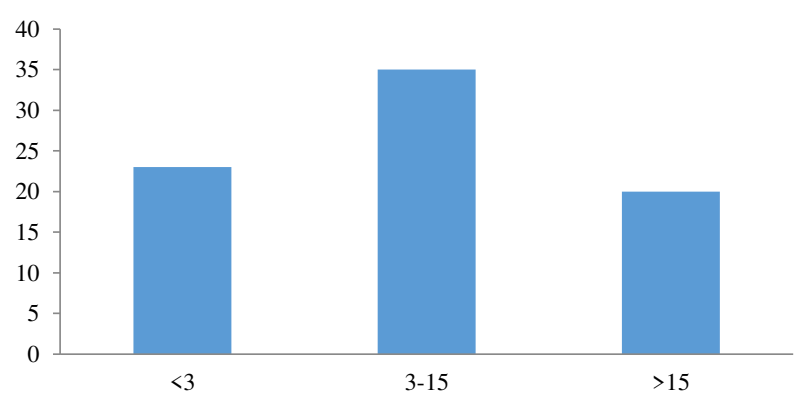

Gambar. 3. Frekuensi setiap kelas fasilitas umum di Surabaya. 
Secara keseluruhan, wilayah Kota Surabaya paling banyak memiliki antara 3 hingga 15 fasilitas umum setiap zona pengamatan yang ditunjukkan oleh Gambar 4.3 dengan frekuensi tertinggi yaitu sebesar 35 zona. Sedangkan terdapat 23 zona yang memiliki jumlah fasilitas umum kurang dari 3 unit. Banyaknya zona yang memiliki fasilitas umum lebih dari 15 yaitu terdapat sebanyak 20 zona. Banyaknya fasilitas umum ini tidak tergantung dari jenis fasilitas umum sehingga kurang memberikan informasi yang mendetail.

\section{Karakteristik Zona Nilai Tanah (ZNT) Berdasarkan Pembagian Wilayah}

Diagram batang dapat digunakan untuk mengetahui frekuensi dari setiap level variabel kategori seperti pada Gambar 4 disajikan karakteristik Zona Nilai Tanah berdasarkan pembagian wilayahnya.

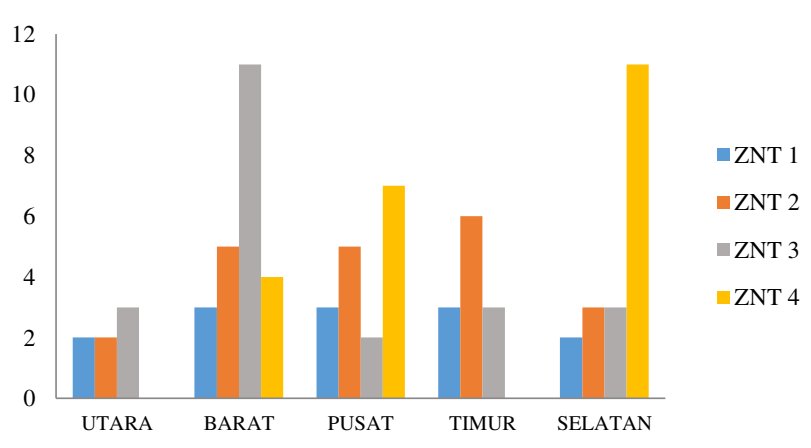

Gambar 4. Frekuensi ZNT berdasarkan Wilayah.

Berdasarkan informasi grafik tersebut diketahui harga tanah dengan kategori tinggi terdapat di wilayah Surabaya Pusat dan Selatan. Zona nilai tanah 3 lebih banyak berada pada wilayah Surabaya Barat dengan frekuensi 11 unit sedangkan untuk zona nilai tanah 4 berada pada wilayah Surabaya Selatan dengan frekuensi 11 unit. Untuk zona nilai tanah 2 lebih banyak berada di wilayah Surabaya Timur dibandingkan dengan wilayah Surabaya lainnya yaitu dengan kisaran harga tanah 2 juta rupiah hingga 3 juta rupiah. Pada wilayah Surabaya Timur dan Surabaya Utara tidak ada zona yang memiliki harga tanah dengan nilai ZNT 4 yaitu antara 4,9 juta rupiah hingga 15 juta.

\section{Karakteristik Fasilitas Umum Berdasarkan Pembagian Wilayah}

Jumlah fasilitas umum di Surabaya berdasarkan wilayah disajikan dalam diagram batang pada Gambar 5.

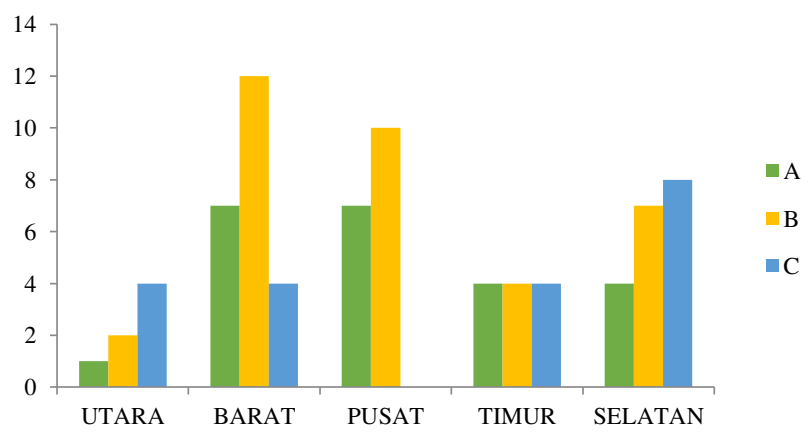

Gambar 5. Banyak Fasilitas Umum Berdasarkan Pembagian Wilayah.

Wilayah yang memiliki jumlah fasilitas umum sebanyak 3 hingga 15 unit (kelas B) berada pada wilayah Surabaya Barat dan Surabaya Pusat. Wilayah Surabaya Selatan dan
Surabaya Utara memiliki banyak fasilitas umum rata-rata lebih dari 15 unit fasilitas umum. Sedangkan di wilayah Surabaya Timur memiliki unit fasilitas umum dengan nilai yang sama untuk setiap kelasnya yaitu bernilai 4 zona. Berdasarkan banyaknya fasilitas umum dan wilayah menunjukkan wilayah yang menjadi pusat perekonomian di wilayah Surabaya yaitu Surabaya Pusat yang tentunya memiliki lebih banyak fasilitas umum karena merupakan pusat kota.

\section{Karakteristik Fasilitas Umum Berdasarkan Zona Nilai Tanah}

Fasilitas umum di Surabaya memiliki zona yang berbedabeda sehingga pada Gambar 6 disajikan diagram banyaknya fasilitas umum berdasarkan ZNT.

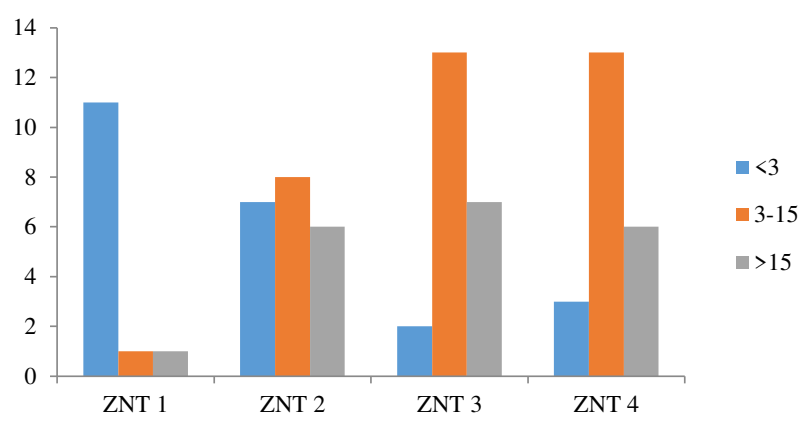

Gambar 6. Karakteristik Fasilitas Umum berdasarkan ZNT.

Berdasarkan Gambar 6 menunjukkan bahwa ZNT 3 dan ZNT 4 memiliki banyak fasilitas umum antara 3 hingga 15 unit begitu pula dengan ZNT 2 yang juga memiliki banyak fasilitas umum dominan adalah antara 3 hingga 5 unit. Sedangkan pada ZNT 1 menunjukkan bahwa banyak fasilitas umum kurang dari 3 unit. Hal ini seharusnya dapat menunjukkan semakin tinggi harga tanah di wilayah tersebut maka didukung pula dengan adanya jumlah fasilitas umum yang lebih banyak juga tetapi karena jenis fasilitas umum dalam hal ini tidak diperhatikan maka dapat terjadi nilai harga tanah tinggi memiliki jumlah fasilitas umum yang tidak banyak.

\section{B. Multiple Correspondence Analysis}

Multiple correspondence analysis merupakan bentuk analisis yang dapat digunakan untuk menganalisis pola hubungan dari beberapa kategori variabel dependen. Dalam penelitian ini variabel dependen yang diteliti yaitu ZNT, banyak fasilitas umum dan pembagian wilayah di Kota Surabaya. Dalam analisis MCA ini akan ditentukan besar dimensi yang akan digunakan dalam menggambarkan plot kecenderungan.

Tabel 4.

Analisis Matriks Indikator

\begin{tabular}{cccc}
\hline \hline Dimensi & Inersia & Proporsi & Kumulatif \\
\hline 1 & 0,5583 & 0,1861 & 0,1861 \\
2 & 0,4975 & 0,1658 & 0,3519 \\
3 & 0,4541 & 0,1514 & 0,5033 \\
4 & 0,3876 & 0,1292 & 0,6325 \\
5 & 0,3344 & 0,1115 & 0,744 \\
6 & 0,2664 & 0,0888 & 0,8328 \\
7 & 0,206 & 0,0687 & 0,9014 \\
8 & 0,1796 & 0,0599 & 0,9613 \\
9 & 0,116 & 0,0387 & 1 \\
\hline \hline
\end{tabular}


Tabel 4 menunjukkan hasil terbaik dengan nilai kumulatif 1 sebesar 9 dimensi. Pada dimensi 1 memiliki nilai inersia 0,5583 artinya bahwa varians matriks indikator untuk dimensi kesatu sebesar 0,5583. Sedangkan nilai inesia dimensi 2 yaitu 0,4975. Pada nilai proporsi inersia menunjukkan proporsi inersia utama matriks indikator terhadap total inersia. Total inersia dalam analisis ini yaitu 3 sehingga proporsi inersia dimensi 1 terhadap total nilai inersia yaitu 0,1861 sedangkan proporsi inersia untuk dimensi 2 yaitu 0,1658 . Hasil terbaik dalam menvisualisasikan hasil korespondensi ZNT, banyak fasilitas umum dan pembagian wilayah dapat dibentuk dalam 9 dimensi namun dalam kenyataannya visualisasi MCA sangat sulit dilakukan jika dimensi yang digunakan sangat besar sehingga untuk mempermudah dalam memvisualisasikan hasil MCA dan interpretasi maka dilakukan dalam dua dimensi. Dengan adanya keterbatasan tersebut, hasil dari MCA nantinya dapat menjelaskan sebesar 35,19\% dari keragaman data.

Setelah ditentukan banyaknya dimensi yang akan digunakan dalam analisis maka perlu diketahui komponen kategori mana saja yang cenderung ke dimensi 1 ataupun ke dimensi 2. Hal tersebut dapat dilihat dari hasil kolom kontributor untuk setiap level variabel kategori dalam Tabel 5 .

Tabel 5.

Kolom Kontributor

\begin{tabular}{|c|c|c|c|c|}
\hline \multirow{2}{*}{ Kategori } & \multicolumn{2}{|c|}{ Komponen 1} & \multicolumn{2}{|c|}{ Komponen 2} \\
\hline & Koordinat & Kontribusi & Koordinat & Kontribusi \\
\hline UTARA & $-0,134$ & 0,002 & $-1,546$ & 0,236 \\
\hline BARAT & 0,12 & 0,006 & $-0,369$ & 0,057 \\
\hline PUSAT & $-0,315$ & 0,028 & 1,148 & 0,367 \\
\hline TIMUR & $-0,808$ & 0,119 & $-0,799$ & 0,116 \\
\hline SELATAN & 0,696 & 0,156 & 0,494 & 0,079 \\
\hline ZNT1 & $-1,667$ & 0,556 & 0,203 & 0,008 \\
\hline ZNT2 & $-0,385$ & 0,054 & $-0,298$ & 0,033 \\
\hline ZNT3 & 0,534 & 0,112 & $-0,865$ & 0,294 \\
\hline ZNT4 & 0,818 & 0,263 & 1,03 & 0,416 \\
\hline$<3$ & 0,657 & 0,277 & 0,057 & 0,027 \\
\hline $3-15$ & 0,228 & 0,075 & 0,048 & 0,018 \\
\hline$>15$ & 0,091 & 0,041 & 0,249 & 0,124 \\
\hline
\end{tabular}

Dalam tabel 4 hanya mengandung komponen 1 dan komponen 2 karena pada hasil matriks indikator telah ditentukan untuk menggunakan dua dimensi saja. Berdasarkan kontribusi terhadap komponen 1 dan komponen 2, setiap kategori variabel memiliki kecenderungan berkontribusi pada salah satu komponen yang dapat dilihat dari nilai kontribusi yang menunjukkan kontribusi terhadap nilai inersia. Berdasarkan wilayahnya, Surabaya Selatan dan Timur cenderung memiliki kontribusi ke komponen 1 dengan nilai kontribusi $15,6 \%$ dan $11,9 \%$, sedangkan wilayah Surabaya Utara, Barat dan Pusat memiliki kecende-rungan berkontribusi ke komponen 2. Pada variabel ZNT yang dibagi menjadi empat kelas ZNT menunjukkan dua ZNT yaitu ZNT1 dan ZNT2 lebih cenderung berkontribusi lebih besar terhadap komponen 1 dan nilai ZNT 3 dan ZNT4 lebih berkon-tribusi terhadap komponen 2. Banyaknya fasilitas umum dibagi menjadi tiga kelas dimana pada kelas A yang memiliki jumlah fasilitas umum kurang dari 3 dan antara 3-15 lebih ber- kontribusi pada komponen 1 sedangkan fasilitas umum dengan jumlah lebih dari 15 unit lebih berkontribusi terhadap komponen 2 dengan besar kontribusi yaitu 12,4\%.

\section{Visualisasi Hasil MCA}

Visualisasi hasil MCA disajikan dengan mengunakan column plot yang didapatkan dari pembentukan antara dua dimensi pada matrik indikator sebelumnya pada setiap kategori yang telah ditentukan. Pada coloumn plot dapat diketahui apakah pada wilayah surabaya, ZNT dipengaruhi oleh banyaknya fasilitas umum dan untuk mengetahui hubungan kedekatan antar kategori. Berikut adalah hasil dari column plot.

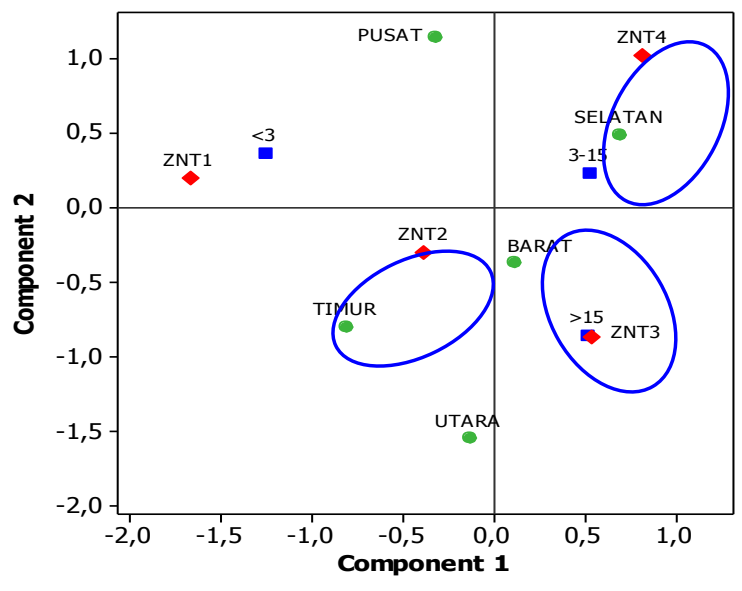

Gambar 7. Hasil Column Plot MCA

Hasil plot juga menunjukkan bahwa terbentuk kelompokkelompok yang memiliki kedekatan antar kategori. Kelompok pertama yaitu ZNT 2 memiliki kecenderungan dengan wilayah Surabaya Timur yaitu dengan kisaran harga tanah antara 2,1 juta hingga 3,1 juta. Kelompok kedua yang terbentuk yaitu wilayah Surabaya Barat dengan nilai ZNT 3 yaitu dengan kisaran harga tanah antara 3 hingga 4,9 juta rupiah memiliki jumlah fasilitas umum lebih dari 15 unit. Jumlah fasilitas umum di wilayah Surabaya Barat tergolong tinggi sehingga harga tanah di wilayah tersebut juga tergolong cukup tinggi. Wilayah Surabaya Selatan memiliki kecenderungan membentuk kelompok dengan nilai ZNT 4 yaitu ZNT dengan harga tertinggi yang berkisar antara 4,9 juta hingga 15 juta rupiah dan dengan jumlah fasilitas umum antara 3 hingga 15 fasilitas umum. Walaupun fasilitas umum di Surabaya Selatan tergolong sedang namun harga tanah di wilayah tersebut sangat tinggi. Hal ini dikarenakan fasilitas umum yang berada di wilayah Surabaya Selatan berupa hotel dan restoran serta kantor pemerintahan. Pada kondisi nyata kantor pemerintah provinsi lebih banyak berada di wilayah Surabaya Selatan dan juga terdapat berbagai hotel dan restoran di wilayah Selatan karena lokasinya yang cukup strategis. Sedangkan untuk kategori yang tidak membentuk kelompok menunjukkan bahwa kategori tersebut tidak memiliki kecenderungan pada satu kategori saja.

\section{KESIMPULAN DAN SARAN}

Setelah dilakukan analisis dan pembahasan mengenai MCA terhadap ZNT, fasilitas umum dan pembagian wilayah di Surabaya didapatkan kesimpulan yaitu berdasarkan wilayah menunjukkan bahwa Surabaya Barat memiliki nilai ZNT 3, Wilayah Surabaya Selatan memiliki ZNT 4, 
Surabaya Timur lebih didominasi oleh ZNT 2 dan wilayah Surabaya Utara memilki ZNT 3. Menurut banyaknya fasilitas umum berdasarkan wilayahnya menunjukkan wilayah Surabaya Barat dan Surabaya Pusat dengan jumlah fasilitas umum 3 hingga 15 unit. Surabaya Selatan memiliki banyak fasilitas umum lebih dari 15 unit. Sedangkan berdasarkan ZNT nya ZNT 1 memiliki jumlah fasilitas umum kurang dari 3 unit dan pada ZNT 2, ZNT 3 dan ZNT 4 didominasi oleh zona yang memiliki banyak fasilitas umum 3 hingga 15. Hasil visualisasi MCA digambarkan dengan column plot yang menghasilkan tiga kelompok yang memiliki kedekatan. Kelompok pertama yaitu ZNT 2 memiliki kecenderungan dengan wilayah Surabaya Timur Kelompok yang terbentuk selanjutnya yaitu wilayah Surabaya Barat dengan nilai ZNT 3 dan banyak fasilitas umum lebih dari 15 unit. Kelompok terakhir yaitu Surabaya Selatan dengan nilai ZNT 4 dan banyak fasilitas umum 3 hingga 5 unit. Namun kondisi harga tanah selalu mengalami perubahan yang sangat cepat sehingga saran untuk penelitian selanjutnya dalam menganalisis harga tanah agar dapat menggunakan data yang lebih update dan dengan ukuran yang lebih besar serta dapat dilakukan dengan soft- ware yang lebih akurat sehingga hasilnya dapat lebih baik lagi.

\section{DAFTAR PUSTAKA}

[1] Badan Pusat Statistik, "Surabaya Dalam Angka 2016," 2016.

[2] Deputi Bidang Survei Pengukuran dan Pemetaan, "Standar Operasional Prosedur Internal Survei Potensi tanah Edisi III/2015," 2015.

[3] M. Greenacre and J. Blasius, Multiple Correspondence Analysis and Related Methods. London: Chapman \& Hall, 2006.

[4] A. Sutawijaya, "Analisis Faktor-Faktor Yang Mempengaruhi Nilai Tanah Sebagai Dasar Penilaian Nilai Jual Obyek Pajak (NJOP) PBB di Kota Semarang," J. Ekon. Pembang., vol. 9, no. 1, 2004.

[5] A. Pangastuti, "Pemetaan Persepsi Merk Laptop di Kalangan Mahasiswa Menggunakan Analisis Korespondensi Berganda," in Seminar Nasional Statistika, 2013.

[6] R. A. Johnson and D. W. Wichern, Applied Multivariate Statistical Analysis. New Jersey: Pearson education, Inc., 2007.

[7] E. J. Beh and R. Lombardo, Correspondence Analysis Theory, Practice and New Strategies. Chichester: John Wiley \& Sons, Ltd, 2014.

[8] G. M. J., Theory and Applications of Correspondence Analysis. London: Academic Press, 1984.

[9] B. Le Roux and H. Rouanet, Geometric Data Analysis. New York: Kluwer Academic Publishers, 2005.

[10]Pemerintah Kota Surabaya, "Pembagian Kecamatan Per Wilayah di Pemerintahan Surabaya," 2015. 